\title{
Effect of Tinting on Value Addition of Tuberose (Polianthes tuberosa L.) cv. Prajwal
}

\author{
Sweta Kumari ${ }^{* *}$ and Prahlad Deb ${ }^{2}$
}

${ }^{1}$ Dept. of Floriculture and Landscape Architecture, Bidhan Chandra Krishi Viswavidalaya, Mohanpur, Nadia, W.B. (741 252), India

${ }^{2}$ Dept. of Horticulture \& Post-Harvest Technology instead Sriniketan, West Bengal (731 235), India

\section{Corresponding Author}

Sweta Kumari

e-mail: sweta.sharmaa89@gmail.com

\author{
Article History \\ Article ID: AR1868 \\ Received in $29^{\text {th }}$ March, 2018 \\ Received in revised form $29^{\text {th }}$ April, 2018 \\ Accepted in final form 26 ${ }^{\text {th }}$ May, 2018
}

\begin{abstract}
Flower craft is one of the most flourish and dynamic enterprises in today's world. In this craft, value addition and postharvest handling methods of cut flowers is a captivating and trilling craft gaining importance now-a-days. Tuberose (Polianthes tuberosa L.) is a popular cut flower having white coloured fragrant blooms. Tinting or artificial colouring of tuberose may be a potential value addition venture. Tinting is an important value addition technique in flower crops where colour pigments are absent or light or dull. Colouring inflorescences with edible dyes enhance the visual appeal of these flowers, increase their economic value and aesthetic beautification. Studies were carried out Tuberose (Polianthes tuberosa L.) cv. Prajwal to evaluate the ability of flower to obtain and retain different colour shades for the elimination of limited acceptability in market which is mainly due to white colour. Six different food dyes were used as tinting agent in the experiment all in powder form viz, Blue, Apple Green, Tomato red, Orange red, Lemon yellow and Rose pink at a concentration of $1 \%$, $2 \%$ and $3 \%$ for all. The darkest shades of colours were obtained in 3\% concentration while lightest shades in $1 \%$. The maximum vase-life was found in tuberose spikes which were treated with $1 \%$ Lemon yellow whereas minimum vase life recorded for Tomato red food dye (3\%). The highest Benefit: Cost ratio was obtained for Lemon yellow food dye (1.83) at concentration of $1 \%$. Blue food dye also obtained better net realization (1.69) at $1 \%$ concentration.
\end{abstract}

Keywords: Food dyes, tinting, tuberose, vase-life

\section{Introduction}

Flowers are the wonderful creations of the nature and are one of the most beautiful gifts of nature and they are integral part of human life even before humans could find speech and alphabets for the dissemination of their ideas and feelings. Different flowers and their colours have played a very vital role in communicating a human feeling, emotion and thought since centuries and this is continued even after man has found verbal language to communicate and even today these flowers and their colours communicate our feelings and emotions with more impart than words.

Tuberose (Polianthes tuberosa L.) a bulbous ornamental plant belongs to the family Amaryllididaceae, In nature, not all flowers are found coloured. Many of them, particularly those bearing fragrance are white in colour like tuberose. They generally do not bear pigments that impart white colour to flower petals. Hence, flowers have to be tint artificially. Tinting is one of the important value addition technologies for imparting desired shades of colours to flowers. Tinting of flowers with dyes can really enhances the value of these flowers, helps the farmers in earning more from their produce and also provides a great variety of colours for aesthetic beautification. Different colouring chemicals like Bromocresol blue, Bromocresol green, Eosine red, Phenol red (Kumar, V., et al., 2003) food dyes like Orange red, Tetrazine red, Lemon yellow, Apple green, Phalsa blue (Sudha D. Patil and B.K. Dhauk., 2008) etc are used for tinting. For value addition in tuberose cut spikes, an investigation for colour induction and post-harvest quality was taken up through chemical colouring agents. Since long, people are trying to colour it either through genetic modification or by artificial dyeing method (Sambandhamurthy, 1980) of late, scientists have got success in inducing colours in hybrids of tuberose by back crossing with other Polianthes spp. (Shen et al., 2000) though they are not released commercially.

Value addition from flowers is including extraction of essential oils, tinting of flowers, flower drying, and preparation of veni, corsage and bountonniere. It is widely grown as specimen for exhibition, cut flowers, artistic garlands, floral ornaments, bouquets and buttonholes. The long flower spikes are excellent as cut flowers for table decoration. The value addition technique like colouring of white flowers can add value up to 5 to 10 times (Mekala et al., 2012). Tinting or artificial colouring of tuberose may be a potential value 
addition venture. An investigation is carried out to study effect of tinting on value addition of tuberose cv. Prajwal to identify the suitable food dyes and its doses. Tinting techniques has already been experimented in tuberose (Sambandhamurthy and Appavu, 1980; Kumar et al., 2003; Mekala et al., 2012) and Lady's Lace (Patil and Dhaduk., 2008).

\section{Materials and Methods}

The site, where experiment was carried out in the departmental laboratory of Department of Horticulture \& Post-Harvest Technology, Palli Siksha Bhavana, Visva-Bharti, Sriniketan during November-December of 2014. Six different food dyes were used as tinting agent in the experiment all in powder form viz, Brilliant Blue (FCF 42090), Apple Green (Tatrazine FCF (19140)+Brilliant Blue FCF (42040), Tomato red (Sunset Yellow FCF (15985)+carmoisine (14720), Orange red (Sunset FCF(15985)+Carmoisine (14720), Lemon yellow (Tetrazine (19140) and Rose pink (Carmoisine (14720)+Brilliant Blue FCF $(42090)$ at a concentration of $1 \%, 2 \%$ and $3 \%$ for all. Different observation like effect of colour and concentration on solution uptake, amount of water absorbed during tinting, spike weight, no of flower open, no of flower drop, flower length and flower diameter were taken. Flowers were harvested in the morning between 8.00 and 9.00 am. Flowers were harvested from farmer field with 2-3 flowers open in each spike. Immediately after harvest, the cut ends of the flower stalks were immersed in water. To prepare $1 \%, 2 \%$ and $3 \%$ of colour solution powder of Blue, Apple green, Lemon yellow, Tomato red, Orange red and Rose pink colour of $1 \mathrm{~g}, 2 \mathrm{~g}$ and 3 $\mathrm{g}$ is mixed in $100 \mathrm{ml}$ of filtrated water. The uniform spikes with $60 \mathrm{~cm}$ stalk length with 2-3 florets opening with 3 spikes were put in conical flask containing $100 \mathrm{ml}$ of edible dye solutions. Each treatment repeated thrice. Spikes were removed from colour solution after 6 hours immediately after it put in vase solution. For preparing $3 \%$ sugar solution about $30 \mathrm{~g}$ sugars was added to 1 litre of distilled water. Citric acid solution of 350 ppm was prepared by dissolving $350 \mathrm{mg}$ of citric acid in 1 liter of water $\left(20^{\circ} \mathrm{C}\right.$ and $\left.\mathrm{RH} 50 \%\right)$. Flasks of $500 \mathrm{ml}$ capacity were used. $200 \mathrm{ml}$ of filtered water used for vase solution. The data were analyzed factorial completely randomized block with 19 treatments and 3 replications. To find out the profit and the value addition in the market price of the coloured spikes as compared to the white ones, a comparison was done by working out the total input and output cost of the dyeing of the spikes and their subsequent sale in the market. The total inputs viz., the cost of spikes, cost of dye were calculated and then subtracted from the actual price obtained from the tinted spikes sold in the market. A benefit cost ratio was worked out to find out the actual profit using the following formula, Benefit cost ratio is equal total money earned from selling the coloured spikes/ total money spent in colouring of spikes.

\section{Results and Discussion}

3.1. Colour solution uptake and amount of water absorbed during tinting $\left(\mathrm{m} /\right.$ spike $\left.^{-1}\right)$

The different food dyes showed significant difference for uptake of colour solution (Table1) maximum amount of colour solution absorbed for Apple green food dye (13.24 ml spike $\left.^{-1}\right)$, where as minimum colour solution absorption found for Tomato red $\left(9.26 \mathrm{ml} \mathrm{spike} \mathrm{s}^{-1}\right)$ food dye tinted spikes. The interaction effect of food dyes and colour concentrations were showed the significant difference for amount of colour solution absorption. The maximum amount of colour solution absorbed in $3 \%$ concentration of Apple green ( $\left.13.8 \mathrm{ml} \mathrm{spike}^{-1}\right)$ followed by Blue food dye, whereas minimum amount of colour solution absorbed in Tomato red dye at $1 \%$ concentration (7 $\mathrm{ml} \mathrm{spike}{ }^{-1}$ ). The colour solution absorption also showed significant difference for the interaction of food dyes and concentration of treatment. As the concentration increased, more edible dye was available to the flowers due to increased amount of edible dye absorption. Sambandhamurthy and Appavu (1980) reported similar findings in their experiment and mentioned of increase in colour shade intensity with increase in concentration of colours.

Water uptake of tinted spikes was showed the significant difference for different food dyes from first to seventh days (Table 1). The spikes treated with Tomato red (3.41 ml spike ${ }^{-1}$ on $4^{\text {th }}$ days ) food dye were lost the capacity to absorb water but those spikes which were treated with other food dyes were absorb water normally during vase life period. The mean water uptake was maximum found in spikes which were treated with Lemon yellow $\left(16.78 \mathrm{ml} \mathrm{spike}^{-1}\right.$ on $4^{\text {th }}$ days) food dye, whereas minimum found in Rose pink treatments. Water uptake of cut spikes was showed significant difference between the treatments and control as well as among

Table 1: Colour solution uptake and amount of water absorbed during tinting ( $\mathrm{ml} \mathrm{spike} \mathrm{e}^{-1}$ )

\begin{tabular}{|c|c|c|c|c|c|c|c|}
\hline $\begin{array}{l}\text { Treat- } \\
\text { ments }\end{array}$ & 1 & 2 & 3 & 4 & 5 & 6 & 7 \\
\hline \multicolumn{8}{|l|}{ Colour } \\
\hline$P_{0}$ & - & 11.11 & 11.0 & 5.22 & 3.37 & 2.12 & 1.58 \\
\hline$P_{1}$ & 12.92 & 13.73 & 7.69 & 10.37 & 8.21 & 4.50 & 1.25 \\
\hline$P_{2}$ & 13.24 & 17.85 & 9.57 & 13.36 & 6.29 & 3.02 & 1.23 \\
\hline$P_{3}$ & 9.94 & 17.29 & 11.50 & 16.78 & 6.18 & 2.56 & 2.53 \\
\hline $\mathrm{P}_{4}$ & 9.26 & 4.48 & 10.75 & 3.41 & 0.00 & 0.00 & 0.00 \\
\hline$P_{5}$ & 9.40 & 5.47 & 2.30 & 2.29 & 1.33 & 0.00 & 0.00 \\
\hline$P_{6}$ & 10.07 & 9.25 & 3.54 & 3.87 & 4.03 & 4.40 & 5.25 \\
\hline SEd \pm & 0.44 & 0.51 & 0.19 & 0.50 & 0.21 & 0.25 & 0.42 \\
\hline$C D$ & 0.88 & 1.04 & 0.38 & 1.011 & 0.42 & 0.51 & 1.47 \\
\hline \multicolumn{8}{|c|}{ Concentration } \\
\hline$C_{1}$ & 10.40 & 11.72 & 7.90 & 9.98 & 5.40 & 1.95 & 1.99 \\
\hline$C_{2}$ & 10.92 & 11.29 & 8.02 & 8.24 & 3.57 & 2.58 & 2.09 \\
\hline $\mathrm{C}_{3}$ & 11.09 & 11.03 & 6.75 & 6.82 & 4.05 & 2.71 & 1.05 \\
\hline $\mathrm{SEd} \pm$ & 0.31 & 0.36 & 0.13 & 0.35 & 0.50 & 0.17 & 0.51 \\
\hline$C D$ & 0.63 & 0.74 & 0.27 & 0.72 & 1.02 & 0.36 & NS \\
\hline
\end{tabular}




\begin{tabular}{|c|c|c|c|c|c|c|c|}
\hline $\begin{array}{l}\text { Treat- } \\
\text { ments }\end{array}$ & 1 & 2 & 3 & 4 & 5 & 6 & 7 \\
\hline \multicolumn{8}{|c|}{ Colour $\times$ Concentration } \\
\hline$P_{1} C_{1}$ & 12.6 & 18.7 & 7.7 & 12.2 & 11.8 & 2.2 & 1.2 \\
\hline$P_{1} C_{2}$ & 12.8 & 14.4 & 10.0 & 9.0 & 2.8 & 4.5 & 2.5 \\
\hline$P_{1} C_{3}$ & 13.3 & 8.1 & 5.4 & 10.0 & 10.1 & 6.8 & - \\
\hline $\mathrm{P}_{2} \mathrm{C}_{1}$ & 12.6 & 17.7 & 9.3 & 20.1 & 1.4 & 4.7 & 2.8 \\
\hline $\mathrm{P}_{2} \mathrm{C}_{2}$ & 13.4 & 17.3 & 11.0 & 13.6 & 9.4 & 3.1 & 0.9 \\
\hline $\mathrm{P}_{2} \mathrm{C}_{3}$ & 13.8 & 18.6 & 8.4 & 6.4 & 8.0 & 1.3 & - \\
\hline$P_{3} C_{1}$ & 9.3 & 14.9 & 12.4 & 17.8 & 11.8 & 1.5 & 2.4 \\
\hline $\mathrm{P}_{3} \mathrm{C}_{2}$ & 10.2 & 18.0 & 10.0 & 16.2 & 3.4 & 3.6 & 3.9 \\
\hline$P_{3} C_{3}$ & 10.3 & 19.0 & 12.1 & 16.4 & 3.4 & 2.6 & 1.3 \\
\hline $\mathrm{P}_{4} \mathrm{C}_{1}$ & 7.0 & 4.2 & 10.3 & 2.1 & - & - & - \\
\hline $\mathrm{P}_{4} \mathrm{C}_{2}$ & 10.3 & 4.2 & 11.7 & 4.3 & - & - & - \\
\hline $\mathrm{P}_{4} \mathrm{C}_{3}$ & 10.4 & 5.0 & 10.3 & 3.9 & - & - & - \\
\hline$P_{5} C_{1}$ & 9.9 & 6.7 & 2.1 & 2.1 & 1.4 & - & - \\
\hline$P_{5} C_{2}$ & 9.3 & 4.9 & 2.3 & 2.3 & 1.7 & - & - \\
\hline$P_{5} C_{3}$ & 9.0 & 4.9 & 2.4 & 2.4 & 0.9 & - & - \\
\hline $\mathrm{P}_{6} \mathrm{C}_{1}$ & 9.8 & 8.2 & 5.7 & 5.7 & 5.9 & 3.3 & 5.5 \\
\hline $\mathrm{P}_{6} \mathrm{C}_{2}$ & 9.8 & 8.9 & 4.1 & 4.1 & 4.2 & 4.3 & 5.2 \\
\hline$P_{6} C_{3}$ & 10.7 & 10.7 & 1.9 & 1.9 & 2.0 & 5.6 & 5.0 \\
\hline SEd \pm & 0.75 & 0.90 & 0.32 & 0.86 & 0.50 & 0.43 & 1.25 \\
\hline$C D$ & 1.54 & 1.81 & 0.65 & 1.75 & 1.02 & 0.88 & NS \\
\hline GM & 10.80 & 11.35 & 7.56 & 8.35 & 4.34 & 2.41 & 1.71 \\
\hline $\begin{array}{l}\mathrm{CV} \\
(\%)\end{array}$ & 8.60 & 9.62 & 5.21 & 12.66 & 14.24 & - & - \\
\hline
\end{tabular}

$\mathrm{CD}(p=0.05) ; \mathrm{P}_{0}$ : (White); $\mathrm{P}_{1}$ : Blue; $\mathrm{P}_{2}$ : Apple green; $\mathrm{P}_{3}$ : Lemon yellow; $P_{4}$ : Tomato red; $P_{5}$ : Orange red; $P_{6}$ : Rose pink; $C_{1}: 1 \%$; $C_{2}: 2 \% ; C_{3}: 3 \%$; Where, $2,3,4,5,6,7$ and 8 were no of days. In table "-"denote that treatment was lost

various treatments, indicating that, there was an adverse effect of only Tomato red dye on the vase life of spikes. The reason being that when flowers are detached from the plant, water loss from these continues through transpiration. The ideal flower preservative was that, which allows water absorption in flower tissues (Salunkhe et al., 1990). Water absorption from the preservative solution maintains a better water balance and flower freshness (Reddy and Singh., 1996) and saves from early wilting resulting inenhanced vase-life. Waithaka et al. (2001) reported that the turgidity in plants and flowers was dependent on the rate of absorption and rate of water loss. In cut flowers, the loss of water from all tissues depends on the environmental factors and immediately after cutting of the flower, a sharp decrease in water loss occurs due to closure of stomata. Floret wilting was mainly due to depleted plant food and the inability of the plant to draw up water which leads to the subsequent colour change and flaccidity of the cell (Ichimura et al., 2002).

\subsection{Effect of colour and concentration on spike weight (g} spike-1)

Spike weight showed the significant difference for different food dyes from day one to seventh days. The spike weight increased from first to third days, where the spike weight was increased maximum in spikes which were treated with, Lemon yellow $48.02 \mathrm{~g} \mathrm{spike}^{-1}$ on $4^{\text {th }}$ days (Table 2 ) increased first 2 days after that it decreased from $3^{\text {rd }}$ days (Table 2). The spike weight was decreased on fourth days, where the maximum spike weight was decreased in Orange red 21.21 g spike ${ }^{-1}$ from on $4^{\text {th }}$ days (Table 2). Generally the weight of cut spikes increases for three days and later decrease in the during vase life period. Spike weight showed the significant difference for concentration of food dyes treatments on fourth to seventh days, where the maximum spike weight was decreased at $3 \%$ food dye treatment, whereas minimum spike weight decreased in control. The reduced spike weight might be due to higher concentration of colour that effect on the cell metabolism when kept in the edible dye solution for $3 \%$ concentration. Maximum spike weight was decreased in higher concentration (Table 2) where the spikes were losing their weight by dropping more number of florets.

\subsection{Number of flower open}

The counting of flower opening started after harvesting of flower till fourth days because maximum no of flower opened during these days and the dropping of flower was almost negligible upto 3 third days and flower dropping start from $4^{\text {th }}$ days. The opening of flower after $4^{\text {th }}$ days was almost negligible. Number of florets opened per day showed the significant difference for different food dyes from one to fourth days, where the maximum number of florets was opened in Apple green, Rose pink, Orange red and Lemon yellow treated spikes whereas minimum opened in Blue edible dye (Table 3 ). Mean number of maximum florets was open in Apple green tinted spikes.

The biological activity of artificial colorants had renewed following the claims that a red food dye was carcinogenic and that some food additives and colorants in particular might be responsible for producing behavioral changes and learning disabilities in children e.g., hyperkinesias, minimal brain disfunction. (Boffey, 1976; Feingold, 1975).

\subsection{Number of flower drop}

The counting of flower dropping started after $4^{\text {th }}$ days till $7^{\text {th }}$ days because maximum no of flower dropped during these days. The dropping of flower is almost negligible upto 3 third days and flower dropping start from $4^{\text {th }}$ days. The opening of flower after $4^{\text {th }}$ days was almost negligible. Number of florets dropping per day showed the significant difference for different food dyes from fourth to seventh day, where the maximum number of florets was dropped in $5^{\text {th }}$ day on Orange red ( 6.56 flower spike ${ }^{-1}$ on $4^{\text {th }}$ days from Table 4 ) there was no effect of different concentration of treated spikes, whereas minimum dropped in control and Blue ( 0.89 flower 


\begin{tabular}{|c|c|c|c|c|c|c|c|c|}
\hline Treatments & 0 & 1 & 2 & 3 & 4 & 5 & 6 & 7 \\
\hline \multicolumn{9}{|l|}{ Colour } \\
\hline $\mathrm{P}_{0}$ & 37.5 & 43.27 & 44.83 & 44.80 & 42.87 & 40.5 & 39.55 & 30.02 \\
\hline $\mathrm{P}_{1}$ & 38.11 & 44.02 & 44.95 & 47.25 & 39.60 & 34.89 & 24.52 & 12.56 \\
\hline $\mathrm{P}_{2}$ & 39.63 & 44.08 & 49.92 & 48.99 & 46.43 & 39.07 & 38.68 & 26.65 \\
\hline $\mathrm{P}_{3}$ & 43.04 & 44.25 & 50.04 & 51.57 & 48.02 & 40.98 & 39.92 & 22.95 \\
\hline $\mathrm{P}_{4}$ & 40.18 & 43.92 & 43.85 & 43.77 & 32.85 & - & - & - \\
\hline$P_{5}$ & 35.52 & 38.66 & 37.43 & 30.74 & 21.21 & - & - & - \\
\hline $\mathrm{P}_{6}$ & 37.49 & 40.92 & 42.70 & 34.29 & 29.66 & 25.08 & 15.37 & 13.46 \\
\hline SEd \pm & 1.75 & 1.81 & 1.98 & 2.08 & 1.76 & 1.66 & - & 3.90 \\
\hline$C D(p=0.05)$ & 3.55 & 3.67 & 4.02 & 4.22 & 3.56 & 3.37 & - & 7.90 \\
\hline \multicolumn{9}{|c|}{ Concentration } \\
\hline$C_{1}$ & 39.75 & 43.41 & 46.38 & 44.89 & 40.67 & 27.64 & 25.24 & 22.12 \\
\hline $\mathrm{C}_{2}$ & 39.00 & 42.75 & 45.35 & 41.42 & 35.88 & 22.55 & 22.08 & 15.69 \\
\hline $\mathrm{C}_{3}$ & 38.24 & 41.77 & 42.71 & 42.01 & 32.33 & 19.82 & 11.92 & 0.00 \\
\hline SEd \pm & 1.24 & 1.28 & 1.40 & 1.47 & 1.24 & 1.17 & 1.76 & 2.76 \\
\hline$C D(p=0.05)$ & NS & NS & 2.85 & 2.98 & 2.52 & 2.38 & 3.56 & 5.59 \\
\hline \multicolumn{9}{|c|}{ Colour $\times$ Concentration } \\
\hline $\mathrm{P}_{1} \mathrm{C}_{1}$ & 38.5 & 44.4 & 50.6 & 51.2 & 48.6 & 43.0 & 40.0 & 37.7 \\
\hline $\mathrm{P}_{1} \mathrm{C}_{2}$ & 40.5 & 45.7 & 46.5 & 46.5 & 41.6 & 36.0 & 33.6 & - \\
\hline$P_{1} C 3$ & 35.3 & 41.9 & 37.8 & 44.0 & 28.7 & 25.7 & - & - \\
\hline $\mathrm{P}_{2} \mathrm{C}_{1}$ & 38.3 & 43.4 & 53.0 & 53.4 & 51.9 & 48.4 & 46.4 & 38.7 \\
\hline $\mathrm{P}_{2} \mathrm{C}_{2}$ & 38.8 & 43.5 & 49.1 & 46.4 & 44.6 & 36.0 & 41.1 & 41.2 \\
\hline $\mathrm{P}_{2} \mathrm{C}_{3}$ & 41.7 & 45.4 & 47.7 & 47.2 & 42.8 & 32.8 & 28.6 & - \\
\hline$P_{3} C_{1}$ & 42.6 & 44.1 & 46.8 & 53.6 & 49.0 & 42.5 & 39.9 & 34.1 \\
\hline $\mathrm{P}_{3} \mathrm{C}_{2}$ & 42.8 & 44.2 & 53.6 & 46.0 & 47.1 & 39.2 & 37.0 & 34.7 \\
\hline $\mathrm{P}_{3} \mathrm{C}_{3}$ & 43.7 & 44.5 & 49.8 & 55.1 & 48.0 & 41.3 & 42.9 & - \\
\hline $\mathrm{P}_{4} \mathrm{C}_{1}$ & 41.2 & 44.3 & 44.1 & 43.8 & 34.2 & - & - & - \\
\hline $\mathrm{P}_{4} \mathrm{C}_{2}$ & 39.2 & 43.3 & 43.0 & 42.6 & 31.3 & - & - & - \\
\hline $\mathrm{P}_{4} \mathrm{C}_{3}$ & 40.2 & 44.1 & 44.5 & 44.9 & 33.0 & - & - & - \\
\hline $\mathrm{P}_{5} \mathrm{C} 1$ & 37.6 & 40.8 & 39.6 & 30.6 & 22.4 & - & - & - \\
\hline$P_{5} C_{2}$ & 35.0 & 37.9 & 37.2 & 31.2 & 21.4 & - & - & - \\
\hline$P_{5} C_{3}$ & 34.0 & 37.3 & 35.5 & 30.4 & 19.8 & - & - & - \\
\hline$P_{6} C_{1}$ & 40.3 & 43.4 & 44.3 & 36.7 & 38.0 & 32.0 & 25.3 & 22.2 \\
\hline $\mathrm{P}_{6} \mathrm{C}_{2}$ & 37.7 & 42.0 & 42.8 & 35.8 & 29.3 & 24.1 & 20.9 & 18.2 \\
\hline $\mathrm{P}_{6} \mathrm{C}_{3}$ & 34.5 & 37.5 & 41.0 & 30.4 & 21.7 & 19.2 & 40.0 & 37.7 \\
\hline SEd \pm & 3.03 & 3.13 & 3.44 & 3.60 & 3.04 & 2.87 & 3.04 & 6.75 \\
\hline $\mathrm{CD}(p=0.05)$ & NS & NS & NS & 7.30 & 6.17 & 5.83 & 6.17 & 13.70 \\
\hline GM & 39.00 & 42.64 & 44.81 & 42.77 & 36.29 & 23.34 & 19.75 & 11.14 \\
\hline CV (\%) & 9.53 & 9.00 & 9.39 & 10.31 & 10.27 & 15.09 & 18.86 & 74.23 \\
\hline
\end{tabular}




\begin{tabular}{|c|c|c|c|c|c|c|c|c|c|c|}
\hline \multicolumn{6}{|c|}{$\begin{array}{l}\text { Table 3: EEffect of colour and concentration on number of } \\
\text { flower open }\end{array}$} & \multicolumn{5}{|c|}{$\begin{array}{l}\text { Table 4: Effect colour and concentration on number of } \\
\text { flower drop }\end{array}$} \\
\hline Treatments & 0 & 1 & 2 & 3 & 4 & Treatments & 4 & 5 & 6 & 7 \\
\hline Colour & & & & & & Colour & & & & \\
\hline$P_{0}$ & 0.41 & 0.24 & 0.34 & 0.44 & 0.41 & $\mathrm{P}_{0}$ & 2 & 6 & 10 & 13 \\
\hline$P_{1}$ & 1.78 & 4.00 & 5.44 & 5.00 & 1.78 & $P_{1}$ & 0.89 & 6.00 & 18.00 & - \\
\hline $\mathrm{P}_{2}$ & 2.22 & 3.22 & 6.22 & 6.67 & 2.22 & $\mathrm{P}_{2}$ & 3.56 & 9.56 & 16.33 & 19.00 \\
\hline $\mathrm{P}_{3}$ & 2.00 & 3.56 & 5.78 & 8.22 & 2.00 & $\mathrm{P}_{3}$ & 4.78 & 9.67 & 17.56 & 19.00 \\
\hline $\mathrm{P}_{4}$ & 2.00 & 3.89 & 6.11 & 5.78 & 2.00 & $\mathrm{P}_{4}$ & 3.00 & - & - & - \\
\hline$P_{5}$ & 1.78 & 5.22 & 7.67 & 7.67 & 1.78 & $P_{5}$ & 6.56 & 19.11 & - & - \\
\hline $\mathrm{P}_{6}$ & 2.00 & 4.78 & 8.33 & 8.56 & 2.00 & $\mathrm{P}_{6}$ & 3.89 & 8.67 & 10.78 & 13.56 \\
\hline SEd \pm & 0.82 & 0.49 & 0.68 & 0.90 & 0.82 & SEd \pm & 0.54 & 0.87 & 1.03 & 0.61 \\
\hline $\mathrm{CD}(p=0.05)$ & 1.94 & 4.06 & 5.72 & 6.78 & 1.94 & $C D(p=0.05)$ & 1.09 & 1.77 & 2.09 & 1.24 \\
\hline Concentration & & & & & & Concentratio & & & & \\
\hline $\mathrm{C}_{1}$ & 2.11 & 4.17 & 6.89 & 6.94 & 2.11 & $\mathrm{C}_{1}$ & 3.11 & 7.22 & 10.33 & 8.39 \\
\hline $\mathrm{C}_{2}$ & 0.28 & 0.24 & 0.24 & 0.31 & 0.28 & $\mathrm{C}_{2}$ & 3.50 & 8.67 & 10.22 & 8.56 \\
\hline $\mathrm{C}_{3}$ & 0.58 & 0.49 & 0.48 & 0.64 & 0.58 & $\mathrm{C}_{3}$ & 4.72 & 10.61 & 10.78 & 8.83 \\
\hline SEd \pm & 1.3 & 4.3 & 4.7 & 5.0 & 1.3 & SEd \pm & 0.38 & 0.62 & 1.48 & 0.43 \\
\hline $\mathrm{CD}(p=0.05)$ & 2.0 & 4.0 & 6.0 & 6.0 & 2.0 & $C D(p=0.05)$ & 0.77 & 1.25 & 0.72 & 0.87 \\
\hline \multicolumn{6}{|c|}{ Colour $\times$ Concentration } & \multicolumn{5}{|c|}{ Colour $\times$ Concentration } \\
\hline$P_{1} C_{1}$ & 2.3 & 3.0 & 6.3 & 6.3 & 2.3 & $P_{1} C_{1}$ & 1.3 & 0.7 & 19.7 & 18.0 \\
\hline$P_{1} C_{2}$ & 2.0 & 3.7 & 6.0 & 7.3 & 2.0 & $\mathrm{P}_{1} \mathrm{C}_{2}$ & 4.0 & 4.7 & 15.7 & 20.0 \\
\hline$P_{1} C_{3}$ & 2.3 & 3.0 & 6.3 & 6.3 & 2.3 & $P_{1} C_{3}$ & 9.0 & 12.7 & 17.3 & 19.0 \\
\hline $\mathrm{P}_{2} \mathrm{C}_{1}$ & 2.0 & 3.7 & 6.0 & 8.7 & 2.0 & $\mathrm{P}_{2} \mathrm{C}_{1}$ & 4.0 & 8.0 & 14.0 & 19.3 \\
\hline $\mathrm{P}_{2} \mathrm{C}_{2}$ & 2.0 & 3.3 & 5.7 & 8.7 & 2.0 & $\mathrm{P}_{2} \mathrm{C}_{2}$ & 4.0 & 8.7 & 18.3 & 19.7 \\
\hline $\mathrm{P}_{2} \mathrm{C}_{3}$ & 2.0 & 3.7 & 5.7 & 7.3 & 2.0 & $\mathrm{P}_{2} \mathrm{C}_{3}$ & 2.7 & 12.0 & 16.7 & 18.0 \\
\hline$P_{3} C_{1}$ & 2.0 & 4.3 & 5.3 & 5.7 & 2.0 & $P_{3} C_{1}$ & 1.7 & 9.0 & 17.0 & - \\
\hline$P_{3} C_{2}$ & 2.0 & 4.0 & 6.7 & 6.0 & 2.0 & $\mathrm{P}_{3} \mathrm{C}_{2}$ & - & 11.3 & 17.3 & - \\
\hline$P_{3} C_{3}$ & 2.0 & 3.3 & 6.3 & 5.7 & 2.0 & $\mathrm{P}_{3} \mathrm{C}_{3}$ & 1.0 & 8.7 & 19.7 & - \\
\hline$P_{4} C_{1}$ & 2.0 & 3.7 & 5.7 & 5.7 & 2.0 & $\mathrm{P}_{4} \mathrm{C}_{1}$ & 3.0 & - & - & - \\
\hline $\mathrm{P}_{4} \mathrm{C}_{2}$ & 1.0 & 5.3 & 9.0 & 8.0 & 1.0 & $\mathrm{P}_{4} \mathrm{C}_{2}$ & 3.3 & - & - & - \\
\hline $\mathrm{P}_{4} \mathrm{C}_{3}$ & 2.3 & 6.7 & 8.3 & 9.3 & 2.3 & $\mathrm{P}_{4} \mathrm{C}_{3}$ & 2.7 & - & - & - \\
\hline$P_{5} C_{1}$ & 2.0 & 5.3 & 6.3 & 9.3 & 2.0 & $P_{5} C_{1}$ & 5.0 & 17.0 & - & - \\
\hline$P_{5} C_{2}$ & 2.0 & 4.3 & 9.7 & 7.3 & 2.0 & $\mathrm{P}_{5} \mathrm{C}_{2}$ & 6.7 & 19.3 & - & - \\
\hline$P_{5} C_{3}$ & 2.0 & 4.7 & 9.0 & 9.0 & 2.0 & $P_{5} C_{3}$ & 8.0 & 21.0 & - & - \\
\hline$P_{6} C_{1}$ & 0.70 & 0.59 & 0.58 & 0.77 & 0.70 & $P_{6} C_{1}$ & 3.0 & 8.7 & 10.0 & 13.3 \\
\hline $\mathrm{P}_{6} \mathrm{C}_{2}$ & 1.42 & 1.21 & 1.19 & 1.56 & 1.43 & $\mathrm{P}_{6} \mathrm{C}_{2}$ & 3.7 & 8.0 & 11.3 & 13.3 \\
\hline$P_{6} C_{3}$ & 1.96 & 4.11 & 6.59 & 6.98 & 1.96 & $\mathrm{P}_{6} \mathrm{C}_{3}$ & 5.0 & 9.3 & 11.0 & 14.0 \\
\hline SEd \pm & 43.8 & 17.83 & 10.92 & 13.50 & 43.85 & SEd \pm & 0.93 & 1.52 & 1.78 & 1.06 \\
\hline $\mathrm{CD}(p=0.05)$ & 1.78 & 4.00 & 5.44 & 5.00 & 1.78 & $C D(p=0.05)$ & 1.88 & 3.07 & 3.61 & 2.15 \\
\hline GM & 2.22 & 3.22 & 6.22 & 6.67 & 2.22 & GM & 3.78 & 8.83 & 10.44 & 8.59 \\
\hline CV (\%) & 2.00 & 3.56 & 5.78 & 8.22 & 2.00 & CV (\%) & 30.14 & 20.01 & 20.89 & 15.11 \\
\hline
\end{tabular}


spike $^{-1}$ ) food dye treated spikes florets dropping were found on fourth day onwards where spikes which were treated with Blue edible dye were did dropped any florets. The florets in Blue edible dye treated spikes wilted but not dropped might be toxic for cell metabolism in the applied treatments, and affected the osmotic pressure of the cells thus altering the cell turgidity. Also this Orange red edible dye might have created blockage during translocation in vascular vessels of the spikes. The different concentrations of food dyes treatments showed significance difference for florets dropping on fourth days and which was showed no significant difference for remaining days. Maximum florets dropping found in 3\% concentration and minimum found in control. The Maximum florets dropping might be due to toxic effect on the cell metabolism when kept in the edible dye solution 3\% concentration. The combined effect for different food dyes, concentrations were showed significant influence on flower dropping where spikes which were treated with blue edible dye were did drop any flower. The florets in Blue edible dye treated spikes wilted but not dropped might be due to higher concentration of colour that affected to the cell metabolism in the applied treatments, and affected the osmotic pressure of the cells thus altering the cell turgidity. The Blue edible dye might create any blockage in the translocation vessels of the spikes. The Maximum florets dropping might be due to toxic effect on the cell metabolism when kept in the edible dye solution 3\% concentration. Flower dropping was more found in higher concentration where the spikes were losing their weight and decreased the vase-life. Amin et al. (2010) reported that tetrazine and carminozine affect adversely and alter biochemical markers in vital organs e.g. Liver and kidney not only at higher dose also at low doses.

\subsection{Flower length $(\mathrm{cm})$ and flower diameter $(\mathrm{cm})$}

Flower length was increases first two days onwards it was decreases maximum flower length. The solution maximum flowers length recorded first days were $\mathrm{P}_{1}, \mathrm{P}_{2}, \mathrm{P}_{6}, \mathrm{P}_{3}, \mathrm{P}_{0}, \mathrm{P}_{4}$ and $P_{5}(4.82,4.81,4.8,4.74,4.71,4.55$ and $4.49 \mathrm{~cm}$ respectively) followed by second day maximum flower length were $P_{5}, P_{2}, P_{1}$, $\mathrm{P}_{3}, \mathrm{P}_{0}, \mathrm{P}_{4}$ and $\mathrm{P}_{6}(5.49,5.41,5.39,5.34,5.33,5.21$ and $5.20 \mathrm{~cm}$ respectively), third day $\mathrm{P}_{5}, \mathrm{P}_{0^{\prime}}, \mathrm{P}_{2}, \mathrm{P}_{1}, \mathrm{P}_{6}, \mathrm{P}_{3}$ and $\mathrm{P}_{4}(5.27,5.26$, $5.26,5.25,5,4.77$ and $4.48 \mathrm{~cm}$ respectively) and on fourth days maximum flower length $\mathrm{P}_{5}, \mathrm{P}_{6}, \mathrm{P}_{2}, \mathrm{P}_{0}, \mathrm{P}_{1}, \mathrm{P}_{4}$ and $\mathrm{P}_{3}$ ( 4.66, 4.6, $4.54,4.46,4.40,3.76$ and $3.55 \mathrm{~cm}$ respectively). The maximum flowers length recorded on first day for different concentration of colour solution $C_{1}, C_{2}$ and $C_{3}$ were $4.66,4.68$ and $4.9 \mathrm{~cm}$ respectively, followed by second day maximum flower length $\mathrm{C}_{1}, \mathrm{C}_{2}$ and $\mathrm{C}_{3}$ were $5.35,5.38$ and $5.4 \mathrm{~cm}$ respectively, third day $C_{1}, C_{2}$ and $C_{3}$ were $5.01,5.03$ and 5.3 respectively and on fourth days maximum flower length $C_{1}, C_{2}$ and $C_{3}(4.09,3.10$ and $4.6 \mathrm{~cm}$ respectively)

The flower flower diameter of tinted tuberose spikes was seen the significant difference for different food dyes from fourth day onwards (Table 5). Flower diameter was an important quality parameter when flowers were kept for interior decoration it made the environment pleasant. The
Table 5: Effect of colour and concentration on flower length and flower diameter $(\mathrm{cm})$

\begin{tabular}{|c|c|c|c|c|c|c|c|c|}
\hline \multirow[t]{2}{*}{$T$} & \multicolumn{3}{|c|}{1} & \multicolumn{2}{|l|}{2} & \multicolumn{2}{|l|}{3} & \multirow{2}{*}{$\begin{array}{r}4 \\
\text { Dia }\end{array}$} \\
\hline & Leng & Dia & Leng & Dia & Leng & Dia & Leng & \\
\hline$P_{0}$ & 4.71 & 3.53 & 5.33 & 4.34 & 5.26 & 4.21 & 4.46 & 3.52 \\
\hline$P_{1}$ & 4.82 & 3.79 & 5.39 & 4.29 & 5.25 & 4.20 & 4.40 & 3.79 \\
\hline$P_{2}$ & 4.81 & 3.74 & 5.41 & 4.36 & 5.26 & 4.29 & 4.54 & 3.61 \\
\hline$P_{3}$ & 4.74 & 3.66 & 5.34 & 4.10 & 4.77 & 3.74 & 3.55 & 2.33 \\
\hline$P_{4}$ & 4.55 & 3.65 & 5.21 & 4.08 & 4.48 & 2.66 & 3.76 & 2.41 \\
\hline$P_{5}$ & 4.49 & 3.66 & 5.46 & 4.38 & 5.27 & 4.28 & 4.66 & 3.69 \\
\hline$P_{6}$ & 4.8 & 3.8 & 5.2 & 4.21 & 5 & 3.93 & 4.6 & 3.67 \\
\hline SEd \pm & 0.07 & 0.06 & 0.05 & 0.03 & 0.07 & 0.04 & 0.08 & 0.10 \\
\hline$C D$ & 0.14 & NS & 0.09 & 0.05 & 0.13 & 0.09 & 0.17 & 0.20 \\
\hline$C_{1}$ & 4.66 & 3.63 & 5.35 & 4.23 & 5.01 & 3.82 & 4.09 & 3.10 \\
\hline$C_{2}$ & 4.68 & 3.70 & 5.38 & 4.25 & 5.03 & 3.88 & 4.10 & 3.30 \\
\hline$C_{3}$ & 4.9 & 3.75 & 5.4 & 4.4 & 5.3 & 4.3 & 4.6 & 3.8 \\
\hline SEd \pm & 0.05 & 0.02 & 0.03 & 0.02 & 0.05 & 0.03 & 0.06 & 0.07 \\
\hline$C D$ & 0.10 & NS & 0.06 & 0.04 & 0.09 & 0.06 & 0.13 & 0.15 \\
\hline$P_{1} C_{1}$ & 4.9 & 3.6 & 5.4 & 4.3 & 5.2 & 4.1 & 4.4 & 3.3 \\
\hline$P_{1} C_{2}$ & 4.9 & 3.9 & 5.4 & 4.3 & 5.3 & 4.2 & 4.4 & 3.3 \\
\hline$P_{1} C_{3}$ & 4.9 & 4.0 & 5.4 & 4.2 & 5.2 & 4.2 & 4.4 & 4.2 \\
\hline$P_{2} C_{1}$ & 4.7 & 3.8 & 5.4 & 4.4 & 5.3 & 4.1 & 4.4 & 3.9 \\
\hline$P_{2} C_{2}$ & 4.5 & 3.8 & 5.2 & 4.4 & 5.3 & 4.4 & 4.4 & 3.8 \\
\hline$P_{2} C_{3}$ & 4.8 & 3.6 & 5.4 & 4.4 & 5.2 & 4.3 & 4.6 & 3.5 \\
\hline$P_{3} C_{1}$ & 4.8 & 3.8 & 5.4 & 4.3 & 5.3 & 4.2 & 4.4 & 3.5 \\
\hline$P_{3} C_{2}$ & 4.8 & 3.7 & 5.3 & 4.1 & 4.8 & 3.85 & 3.8 & 2.5 \\
\hline$P_{3} C_{3}$ & 4.6 & 3.7 & 5.4 & 4.1 & 4.8 & 3.75 & 3.3 & 2.4 \\
\hline $\mathrm{P}_{4} \mathrm{C}_{1}$ & 4.9 & 3.6 & 5.4 & 4.1 & 4.8 & 3.7 & 3.6 & 2.1 \\
\hline$P_{4} C_{2}$ & 4.7 & 3.7 & 5.2 & 4.1 & 4.6 & 3.0 & 3.8 & 2.7 \\
\hline$P_{4} C_{3}$ & 4.6 & 3.5 & 5.3 & 4.0 & 4.5 & 2.5 & 3.7 & 2.2 \\
\hline$P_{5} C_{1}$ & 4.4 & 3.7 & 5.1 & 4.1 & 4.4 & 2.5 & 3.8 & 2.3 \\
\hline$P_{5} C_{2}$ & 4.4 & 3.8 & 5.6 & 4.5 & 5.4 & 4.4 & 4.2 & 3.9 \\
\hline$P_{5} C_{3}$ & 4.4 & 3.5 & 5.4 & 4.4 & 5.2 & 4.3 & 4.0 & 3.7 \\
\hline$P_{6} C_{1}$ & 4.4 & 3.7 & 5.4 & 4.2 & 5.2 & 4.2 & 4.0 & 2.21 \\
\hline$P_{6} C_{2}$ & 4.68 & 3.69 & 5.36 & 4.26 & 5.05 & 3.90 & 4.13 & 3.23 \\
\hline$P_{6} C_{3}$ & 4.71 & 3.7 & 5.33 & 4.21 & 5.26 & 2.39 & 4.46 & 3.5 \\
\hline SEd \pm & 0.13 & 0.11 & 0.08 & 0.04 & 0.12 & 0.07 & 0.15 & 0.17 \\
\hline$C D$ & 0.25 & 0.23 & 0.16 & 0.09 & 0.24 & 0.15 & 0.31 & 0.35 \\
\hline GM & 4.82 & 3.53 & 5.39 & 4.34 & 5.25 & 4.21 & 4.40 & 3.52 \\
\hline $\begin{array}{l}\text { CV } \\
\text { (\%) }\end{array}$ & 30.14 & 3.79 & 20.01 & 4.29 & 20.89 & 4.20 & 15.11 & 3.79 \\
\hline CD: & $=0$ & & & & & & & \\
\hline
\end{tabular}


maximum flowers diameter recorded on first day for different colour solution $\mathrm{P}_{6}, \mathrm{P}_{1}, \mathrm{P}_{2}, \mathrm{P}_{5}, \mathrm{P}_{3}, \mathrm{P}_{4}$ and $\mathrm{P}_{0}$ were 3.81, 3.79, $3.74,3.66,3.66,3.65$ and $3.53 \mathrm{~cm}$ respectively, followed by second days maximum flower diameter were $\mathrm{P}_{5}, \mathrm{P}_{2}, \mathrm{P}_{0^{\prime}}, \mathrm{P}_{1}, \mathrm{P}_{6}$, $P_{3}$ and $P_{4}$ were 4.38, 4.36, 4.34, 4.29, 4.21, 4.10 and $4.08 \mathrm{~cm}$ respectively, third day $\mathrm{P}_{2}, \mathrm{P}_{5}, \mathrm{P}_{0}, \mathrm{P}_{1}, \mathrm{P}_{6}, \mathrm{P}_{3}$ and $\mathrm{P}_{4}$ were (4.29, $4.28,4.21,4.20,3.933 .74$ and $2.66 \mathrm{~cm}$ respectively) and on fourth days maximum flower length in $P_{1}, P_{5}, P_{6}, P_{2}, P_{0}, P_{4}$ and $P_{3}(3.79,3.69,3.67,3.61,3.52,2.41$ and $2.33 \mathrm{~cm}$ respectively). The maximum flowers diameter recorded on first day for different concentration of colour solution $\mathrm{C}_{1}, \mathrm{C}_{2}$ and $\mathrm{C}_{3}$ were $3.63,3.70$ and $3.75 \mathrm{~cm}$ respectively, followed by second day maximum flower diameter $\mathrm{C}_{1}, \mathrm{C}_{2}$ and $\mathrm{C}_{3}$ were $4.23,4.25$ and $4.4 \mathrm{~cm}$ respectively, third day $C_{1}, C_{2}$ and $C_{3}$ were $3.82,3.88$ and $4.3 \mathrm{~cm}$ respectively and on fourth days maximum flower diameter $C_{1}, C_{2}$ and $C_{3}(3.10,3.30$ and $3.8 \mathrm{~cm}$ respectively).

The spikes harvested at tight bud stage i.e. 1-2 basal florets show colour there may be adequate availability of sucrose which might have facilitated higher rate of respiration necessary for cell division, cell expansion and providing carbon skeleton for the tissue structure contributing to floret expansion, formation of cell constituents and thus caused increased floret size (Alka Singh et al., 2005). Similar results were found by Mahesh et al. (2011); B. Sravan Kumar et al. (2015) in gladiolus.

The floret diameter of tinted tuberose spikes showed the significant difference for different food dyes from fourth day onwards (Table 5). Floret diameter increases first 2 days after that it decreases. The same result was observed by (Bhattacharjee et al., 2003) on Postharvest quality of tuberose spikes as affected by colouring agents and storage. The maximum floret length increase was observed in Pink rose $\left(1^{\text {st }}\right.$ days $4.38 \mathrm{~cm}$ ), whereas minimum found in Orange red food dye $\left(4.08 \mathrm{~cm}\right.$ on $1^{\text {st }}$ days) fourth day.

\subsection{Vase life of tinted flowers (Days)}

Different food dyes showed significant difference for vase-life of cut spikes from (Table-1, 2, and 4), the maximum vase-life was found in control (7 days), whereas minimum vase-life recorded for Tomato red food dye (4 days) tinted spikes. Vase-life of tuberose cut spikes showed significant difference for concentration of food dyes treatments. Maximum vaselife was recorded for $1 \%$ concentration (7 days), whereas minimum vase-life was found in $3 \%$ concentration. The interaction of different food dyes and their concentration of treatment showed significance difference for vase-life for tuberose cut spikes. Maximum vase-life recorded for all the food dyes at $1 \%$ (7.00 days) whereas minimum vase-life was found in Tomato red at 3\% (4 days). The vase of cut spikes was decreased with increased in concentration. There was significant difference found in the vase-life observed when the spikes were exposed to varying concentration of immersion for all the dyes, indicating that there is an adverse effect of the time of immersion on the vase-life of the spikes of cv. Prajwal. The reduced vase-life might be due to toxic effect on the cell metabolism when kept in the edible dye solution for
$3 \%$ concentration of immersion. Flower dropping was more found in higher concentration of $3 \%$ where the spikes were losing their weight and decreased the vase-life. The flowers were not properly opened after the dyeing with Tomato red at $3 \%$ per cent concentration of food dyes. The biological activity of artificial colorants has renewed following the claims that a red food dye is carcinogenic and that some food additives and colorants in particular might be responsible for producing behavioral changes and learning disabilities in children e.g., hyperkinesias, minimal brain dysfunction (Boffey., 1976; Feingold., 1975).

\subsection{Economics of tinted spikes}

The colour shade obtained by lemon yellow edible dye was

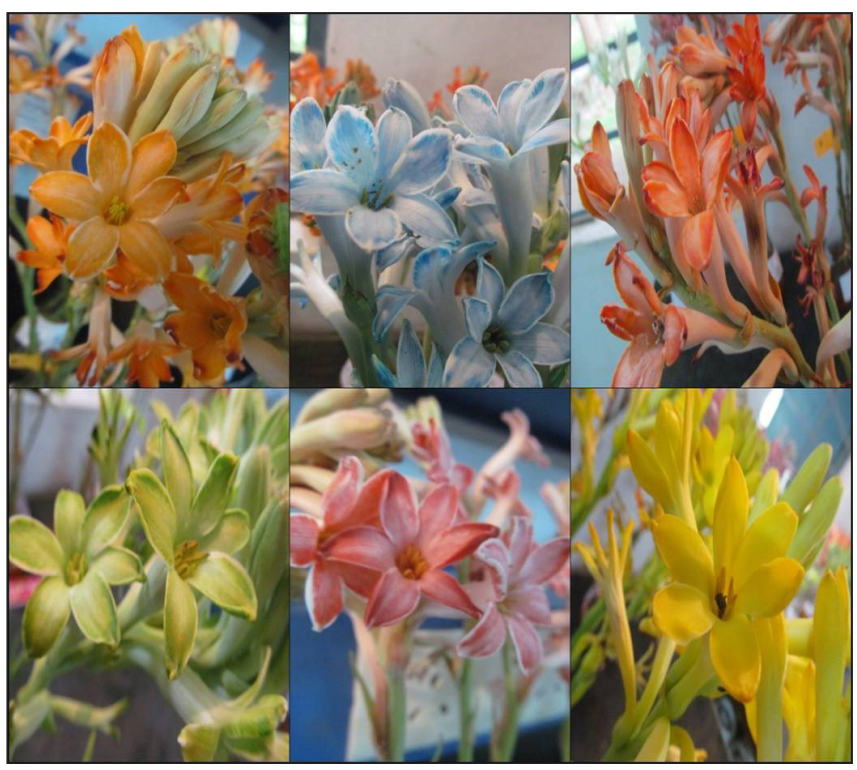

Figure 1: Top row from left Orange red, Blue, Tomato red; Bottom row from left Apple green, Pink rose, Lemon yellow

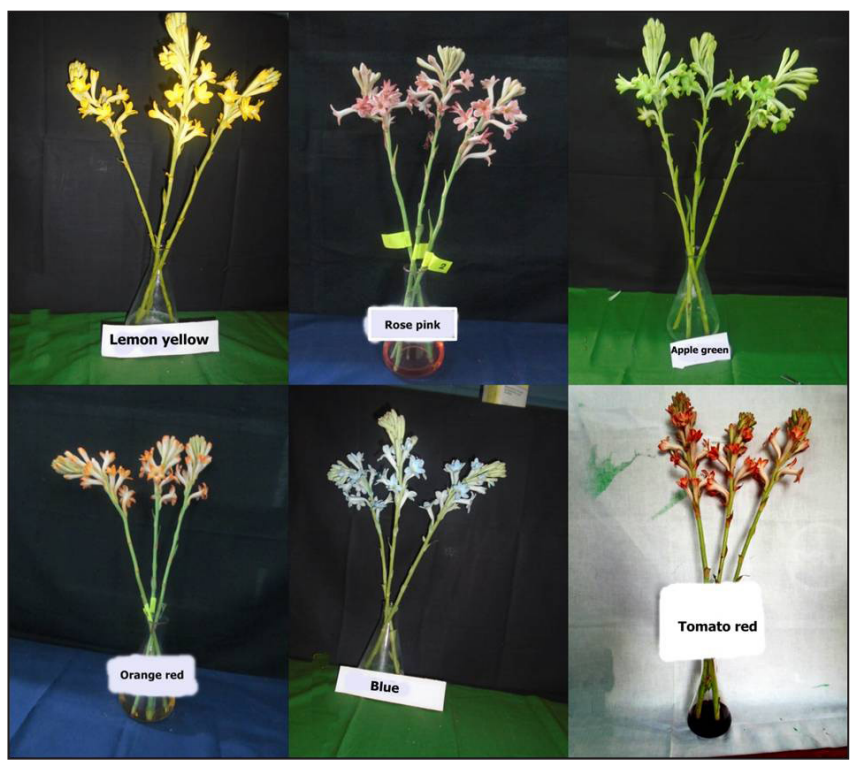

Figure 2: Top row from left Lemon yellow, Rose pink, Apple green; Bottom row from left Orange red, Blue, Tomato red 
looks more beautiful and naturalistic and very attractive among all colours, because the highest net realization per spike was (₹ 4.76) obtained. Blue food dye also obtained better net realization ( $₹ 4.01$ ) since the colour pattern obtained by this dye was different from other dyes and looks very beautiful. Similarly other dyes also got good realization but Tomato red dye did not gained much realization since it vase-life was very less that was 4 days (Table 6 ).
The economics of colouring of tuberose spikes was highly effective for lemon yellow edible dye. The highest $\mathrm{B}: \mathrm{C}$ ratio was obtained for lemon yellow food dye (1.83) at concentration of $1 \%$. Blue food dye also obtained better net realization (₹ 1.69) at $1 \%$ concentration since the colour pattern obtained by this dye was different from other dyes and looks very beautiful. The $B: C$ ratio of tinted spikes was not much varied with the concentrations of food dyes.

\begin{tabular}{|c|c|c|c|c|c|c|c|c|}
\hline $\begin{array}{l}\text { Food } \\
\text { dyes }\end{array}$ & $\begin{array}{l}\text { Treat- } \\
\text { ments }\end{array}$ & $\begin{array}{l}\text { Cost of dye } \\
\left(₹ \text { spike }^{-1}\right)\end{array}$ & $\begin{array}{l}\text { Cost of spike } \\
\left(₹ \text { spike }^{-1}\right)\end{array}$ & $\begin{array}{l}\text { miscel- } \\
\text { laneous }\end{array}$ & $\begin{array}{l}\text { Total input } \\
\left(₹ \text { spike }^{-1}\right)\end{array}$ & $\begin{array}{l}\text { Total income } \\
\left(₹ \text { spike }^{-1}\right)\end{array}$ & $\begin{array}{l}\text { Net realization } \\
\left(₹ \text { spike }^{-1}\right)\end{array}$ & $\begin{array}{l}\mathrm{B}: \mathrm{C} \\
\text { ratio }\end{array}$ \\
\hline \multirow[t]{3}{*}{$P_{1}$} & $1 \%$ & 0.23 & 5.00 & 0.5 & 5.73 & 9.7 & 3.97 & 1.69 \\
\hline & $2 \%$ & 0.46 & 5.00 & 0.5 & 5.96 & 9.97 & 4.01 & 1.62 \\
\hline & $3 \%$ & 0.70 & 5.00 & 0.5 & 6.20 & 10.17 & 3.98 & 1.64 \\
\hline \multirow[t]{3}{*}{$P_{2}$} & $1 \%$ & 0.28 & 5.00 & 0.5 & 5.78 & 8.28 & 2.4 & 1.43 \\
\hline & $2 \%$ & 0.56 & 5.00 & 0.5 & 6.06 & 8.56 & 2.5 & 1.41 \\
\hline & $3 \%$ & 0.85 & 5.00 & 0.5 & 6.35 & 8.85 & 2.5 & 1.39 \\
\hline \multirow[t]{3}{*}{$P_{3}$} & $1 \%$ & 0.22 & 5.00 & 0.5 & 5.72 & 10.47 & 4.51 & 1.83 \\
\hline & $2 \%$ & 0.46 & 5.00 & 0.5 & 5.96 & 10.71 & 4.75 & 1.79 \\
\hline & $3 \%$ & 0.65 & 5.00 & 0.5 & 6.15 & 10.91 & 4.76 & 1.77 \\
\hline \multirow[t]{3}{*}{$P_{4}$} & $1 \%$ & 0.23 & 5.00 & 0.5 & 5.73 & 6.73 & 1 & 1.17 \\
\hline & $2 \%$ & 0.46 & 5.00 & 0.5 & 5.96 & 6.86 & 0.9 & 1.15 \\
\hline & $3 \%$ & 0.70 & 5.00 & 0.5 & 6.2 & 7.2 & 0.84 & 1.16 \\
\hline \multirow[t]{3}{*}{$P_{5}$} & $1 \%$ & 0.3 & 5.00 & 0.5 & 5.8 & 8.1 & 2.30 & 1.39 \\
\hline & $2 \%$ & 0.6 & 5.00 & 0.5 & 6.1 & 8.13 & 2.03 & 1.33 \\
\hline & $3 \%$ & 0.9 & 5.00 & 0.5 & 6.4 & 8.33 & 1.93 & 1.30 \\
\hline \multirow[t]{3}{*}{$P_{6}$} & $1 \%$ & 0.26 & 5.00 & 0.5 & 5.76 & 7.16 & 1.40 & 1.24 \\
\hline & $2 \%$ & 0.53 & 5.00 & 0.5 & 6.03 & 7.38 & 1.35 & 1.22 \\
\hline & $3 \%$ & 0.8 & 5.00 & 0.5 & 6.3 & 7.6 & 1.30 & 1.20 \\
\hline
\end{tabular}

\section{Inference}

Different food dyes representing colours likes Blue, Apple green, Lemon yellow, Tomato red, Orange red and Rose pink and different concentration significantly affected the vaselife of flower with respect to different parameters like water uptake, flower weight, flower diameter, flower length, flower opening and flower dropping. The flowers remained maximum fresh with higher vase life in Lemon yellow followed by Rose pink and Apple green. Lower concentration of food dyes (1\%) exhibited higher freshness and highest vase life of flowers.

\section{Reference}

Amin, K.A., Abdel, H., Hameid, A.H., Elstar, A., 2010, Effect of food and azo dyes tetrazine and carminozine on biochemical parameters related to renal hepatic function and oxidative stress, biomarkers in young male rats. Food and Chemical Toxicity 48, 2994-2995.
Boffey, P.M., 1976. Color additives: botched experiment leads to banning of Red Dye No. 2. Science 191, 450-451.

Feingold, B.F., 1975. Why Your Child is Hyperactive (Random House, New York) 8, 537-538.

Ichimura, K., Kawabata, Y., Kishimoto, M., Goto, R., Yamada, K., 2002. Variation with the cultivar in the vase life of cut rose flowers. Bulletin of the National Institute of Floricultural Science 2, 9-20.

Jain, R., Janakiram, T., Kumawat, G.L., 2015. Studies on postharvest attributes of tuberose (Polianthes tuberosa) cultivars as influenced by tinting with edible colours. Current Horticulture 3(2), 18-24.

Kumar, V., Battacharjee, S.K., Rajive Kumar, R., Misra, L., Krishnan, P.S., 2003. Post harvest and quality of tuberose spikes as affected by colouring agents and storage. Journal of Ornament Horticulture 6(2), 119.

Mekala, P., Ganga, M., Jawaharlal, M., 2012. Artificial colouring of tuberose flowers for value addition. South Indian 
Horticulture 60, 216-223.

Mahesh, C., Moond, S.K., Kumara, A., Beniwal, B.S., 2011. Response of vase solution on keeping quality of cut spikes of gladiolus cv. Priscilla. Asian Journal of Horticulture 6(2), 319-321.

Reddy, B.S., Singh, K., Singh, A., 1995. Effect of sucrose, citric acid and 8-Hydroxyquinoline sulphate on the postharvest physiology of Tuberose cv. Single. Advanced Agriculture Research in India 3, 161-167.

Salunkhe, D.K., Bhat, N.R., Desai, B.B., 1990. Post-harvest biotechnology of flowers and ornamental plants. Springer- Verlag, Berlin, 192.

Sudha, D., Patil and B.K., Dhaduk, 2008, Value addition of Lady's Lace (Pimpinella monoica) cut flower by colouring with edible dyes. Journal of Ornamental Horticulture, 11(1), 32-36.

Sambandhamurthy, S., Appavu, K., 1980. Effect of the chemicals on the colouring of tuberose (Polyantha tuberose L.). National seminar on production technology of Horticultural crops. South Indian Horticulture 7(2), 103-104.
Shen, T.M., Du, T.S., Huang, B.S., Huang, T.S., Shen, R.S., 2000. Breeding for new flower colours in Poliantha tuberose Linn. Journal of Chinese Society Horticulture Science 43, 358-367.

Sravan Kumar, P.B., Lalitha Kameswari, M., Pratap and Venkateswarrao, P., 2015. Studies on vase life of tinted spikes of gladiolus cultivar white prosperity. Indian Journal of Agricultural Research 49(1), 71-76.

Singh. A., Kumar, J., Kumar, P., Singh, V.P., 2005. Influence of 8-Hydroxy Quinoline (8-HQ) and sucrose pulsing on membrane stability and postharvest quality of gladiolus cut spikes. Journal of Ornamental Horticulture 8(4), 243-248.

Waithaka, K., Reid, M.S., Dodge, L.L., 2001. Cold storage and flower keeping quality of cut tuberose (Polianthes tuberosa L.). Journal of Horticultural Science and Biotechnology 76, 271-275.

Zhang, Y., Li, S., Wu, X., 2008. Pressurized liquid extraction of flavonoids from Houttuynia cordata Thunb. Separation and Purification Technology 58, 305-310. 